\title{
O Curso do Discurso: Leitura de $O$ Cão Sem Plumas de João Cabral de Melo Neto
}

Editado pelo próprio poeta em Barcelona, em 1950, o seu quinto livro, o longo texto $O$ cão sem plumas, de quatrocentos e vinte e seis versos, tem parecido aos seus melhores críticos o marco de uma nova fase de sua atividade.

No entanto, se visto por um ângulo que o relaciona, como precursor, ao que Crespo-Bedate chamaram de "tríptico do Capibaribe" 1 o poema é, de fato, o início de uma preocupação explícita com o regional que não estava nas obras anteriores, nem por isso pode-se afirmar sumàriamente, como fazem aqueles autores, que até então o autor cumpria "meticulosa e friamente sua primeira etapa poética, que é a do aperfeiçoamento do instrumental, da forma". ${ }^{2}$ Mesmo porque a ausência de uma preocupação com o regional nos textos precedentes só superficialmente é verdadeira: o fato de iniciar a sua atividade sob o pêso do fastígio do Regionalismo, e existindo numa região propícia à sua adoção, foi importante fator na determinação do modo pelo qual João Cabral respondeu ao que então se fazia em têrmos de literatura.

Por outro lado, a afirmação de que, numa primeira fase, o poeta fôra apenas dando cumprimento a um "aperfeiçoamento do instrumental, da forma" é feita às custas de tudo o que, naqueles primeiros textos, representa de trabalho desenvolvido no sentido de atingir uma mais estreita vinculação entre o fazer e o dizer que, naturalmente, a concepção de forma revelada pelos críticos espanhóis impede.

Está claro que a afirmação acêrca do valor dos textos anteriores emitida por aquêles críticos tem de ver, sobretudo, com o desvio dicotômico que orienta as suas reflexões. Dizer que a obra de João Cabral, que se estende de Pedra do Sono à Psicologia da Composição, "tem por objeto poético, por matéria, a própria poesia" 3 e que, por isso, com o poema de 1950, "Cabral se situará à margem de sua própria produção 
poetica" 4 é, sem dúvida, aceitar muito literalmente a divisão em "duas águas" proposta pelo próprio autor na reunião de seus poemas em 1956.

É, por outro lado, a meu ver, reduzir a tensão, por assim dizer, dialética existente entre os vários poemas que compõem o longo texto de suas Poesias Completas; o didaticismo da divisão de dois poetas num só, "duas águas", não faz justiça à complexidade de seu texto.

O que pretendo mostrar é precisamente a maneira pela qual é possível ver o seu texto como tensão, e não resolução, entre o fazer e o dizer-sistema de convergências, sempre precário, através do qual o poeta se situa e se define ao situar e definir os rumos de sua obra.

Neste sentido, vale a pena transcrever trecho do ensaio de Haroldo de Campos sôbre o poeta, em que se afirma não sòmente o teor dialético de sua poesia, como as consequências críticas, e para a crítica, da observação.

"Que sua poesia- diz o crítico- é dialética não para o confôrto de alguma síntese ideal, hipostasiada no absoluto, mas pela guerra permanente que engendra entre os elementos em conflito, à busca de conciliação, e onde o possível se substitui normativamente ao eterno". 5

Assim sendo, a bifurcação das duas fases sugeridas pelos críticos espanhóis, e por quase todos os seus críticos, parece orientada no sentido de atingir aquela "síntese ideal" mencionada por Haroldo de Campos.

$\mathrm{Na}$ verdade, nem na obra anterior à de 1950 inexistem os elementos que caracterizam uma reflexão cerrada quanto à historicidade da poesia, dando como resultado aquilo que, sendo inicialmente recusa, termina por ser cêrco da temporalidade, nem n'O cão sem plumas a imersão no Tempo, na Cidade dos homens, se faz sem a radicalização do processo de desmontagem interna do próprio poema, sobretudo através do elemento que dá origem à singularidade do poeta dentro de sua geração: o tratamento da imagen.

Por isso mesmo, quando acêrca da "Antiode" fala-se em "volta à realidade circunstancial" o alvo da assertiva não é tão só a obra de João Cabral, o seu percurso, como tôda uma literatura que, imersa na circunstância, não passara pela operacão redutora do ideal à linguagem, da flor à palavra flor.

Que esta operação agora, aliada ao recurso do uso estratégico da imagem como instrumento de mediação entre o poeta e a realidade circunstancial, apareça possibilitando um discurso não sòmente histórico, mas regional, é antes coerente em face de sua evolução do que, como querem Crespo-Bedate, isolador com relaçãoà sua própria obra.

Mais tarde, no poema "Rios sem discurso", d'A Educação pela Pedra, João Cabral ainda mais intensificará a dependência entre objeto e linguagem.

Por enquanto, neste texto de 1950, ainda existe o discurso e a fábula pelos quais o Capibaribe conta de seu curso. A configuração do sistema mais 
amplo procurado pelo poeta no texto futuro- rio/linguagem- tem, não obstante, a sua origem aqui: imagem, no poema, é linguagem e é isto o que $O$ cão sem plumas deixa ver bem claro.

\title{
II
}

Estruturado em quatro partes- duas paisagens, uma fábula e um discurso-, desde o seu título o poema propõe a redução pela imagem,ampliando o processo que já se intensificara na "Antiode": a condição do rioé dada pela duplicidade, imagem dentro da imagem, da metáfora escolhida. Mais ainda, a própria utilização do têrmo plumas em uso negativo mostra de que modo o trabalho no eixo paradigmático, o da seleção, no poema, tem consequências sintagmáticas: a negatividade é maior na medida em que aquilo que se nega ao sujeito, cão/rio, é por experiência repertorial, o que no léxico tem mais valor. Por ser "especialmente destinada a adornos", 60 nome escolhido para penas é irônico desde que o seu uso, sabe-se logo, tem direção negativa: é por ser "sem plumas", e não "sem penas", que a condição do cão/rio não permite, assim como os "sem discurso" do poema posterior, o adôrno, a linguagem de adôrno, por meio da qual os seus olhos aparecem "pintados de azul nos mapas", como se diz na ultima estrofe da primeira paisagem.

Da mesma maneira, ainda quanto à designação, a terceira estrofe do poema, ao oferecer uma definição do título, usa da crítica implícita a outras designações possíveis, desta vez em têrmos historicizados:

"Aquêle rio

era como um cão sem plumas.

Nada sabia da chuva azul, da fonte côr de rosa,

da água do copo de água, da água de cântaro, dos peixes de água, da brisa na água."

Sendo assim, jogando com expressões já consumidas em sua própria obra (como, por exemplo, a aura semântica que circunda o "copo de água", que aparece no poema "O Engenheiro", ou a brisa do último verso), com qualificações equivalentes a plumas do título ("chuva azul", "fonte côr de rosa", "água de cântaro") e, sobretudo, com o verbo (saber), João Cabral desdobra a metáfora-título no momento em que, por oposição, revela a condição negativa do rio/cão.

\author{
"Sabia dos caranguejos \\ de lodo e ferrugem. \\ Sabia da lama \\ como de uma mucosa. \\ Devia saber dos polvos. \\ Sabia seguramente \\ da mulher febril que habita as ostras."
}


O "conhecimento" que se evitava em textos anteriores em função de um fazer que sòmente o "sono do jardineiro", como diz na "Antiode", permitiria, é agora revelado através do rio/cão. Em oposição simétrica às qualificações equivalentes a plumas da estrofe anterior, "caranguejos de lodo e ferrugem", "lama", "polvos" e "mulher febril" constituem a matéria de seu conhecimento. Transformada em instrumento de nomeação da realidade, a metáfora-título é capaz de veicular aquelas coisas de que o poeta "desesperava por não saber falar delas em verso": para um "cão sem plumas", o "adôrno" do verso não tem importância. Desta maneira, à medida que o rio/cão tem o seu saber definido, êle não sabe isto mas aquilo, o poeta, que vê a realidade por êle, também sabe. É assim que as duas estrofes iniciais do poema propõe a sua, do poeta, percepção do rio e suas relações com o espaço, cidade, em que existe.

Conservado em posição de passividade, o espaço do rio germina as imagens de oposição que serão, em seguida, renovadas: rua, cachorro, fruta e espada, identificados pelo mesmo verbo na passiva (é passada) se diferenciam desde que apontam para ordens diversas da realidade, assim como o percurso do rio desdobra-se em duas paisagens. Na verdade, o que possibilita e elisão do verbo entre o quarto e o quinto versos("uma fruta/por uma espada") é exatamente aquilo que Benedito Nunes observou: "Em vez de uma comparação entre têrmos diferentes, temos uma comparação entre relações que se assemelham (...)"7.

Precisamente por serem relações, e não têrmos, que se comparam, assim como cidade e rio se comparam no corpo do texto, é que é possível jogar com duas ordens semânticas diversas (rua-fruta, cachorro-espada), identificadas pelo verbo na passiva. É isto, por outro lado, que leva à exposição da trama imagística da estrofe, desnudando a metáfora-título a seguir, sem, entretanto, deixar de semear o que, depois, será, para utilizar a expressão de Umberto Eco, a "metáfora epistemológica" do poema, isto é, o conhecimento da realidade atingido por meio da linguagem. Pela destruição (desnudamento) da metáfora possível com base nos têrmos de que se utiliza, João Cabral atinge a construção de uma trama de relações que orienta tanto o seu "saber", quanto o do cão/rio. Dêste modo, o conhecimento do último na quarta estrofe só foi possível porque o do poeta foi revelado na crítica interna e destrutiva das três primeiras. O conhecimento da "mulher febril" é identificado com o de caranguejos e lama porque, antes, estratègicamente, já haviam sido confundidas as ordens natural (rio)e histórica (cidade). É o que, sem dúvida, admite, nesta primeira paisagem, o discurso, não ainda do rio - o que só vai ocorrer na parte final do poema, mas acerca do rio e de sua paisagem tanto natural quanto histórica. Sobretudo esta última é o que se visa com o aproveitamento daquela.

Neste sentido, por exemplo, sobreleva o tratamento pelo poeta, nas quinta e sexta estrofes, daquilo que é possível ler, decifrar, no próprio movimento do rio/cão e que vai determinar a formação das imagens nas estrofes seguintes. Assim como nas anteriores a relação era estabelecida em 
têrmos de não saber/saber, agora o sistema é fundado na oposição não abrir/abrir:

"Aquêle rio

jamais se abre aos peixes, ao brilho,

à inquietação de faca

que há nos peixes.

Jamais se abre em peixes.

Abre-se em flôres

pobres e negras

como negros.

Abre-se numa flora

suja e mais mendiga

como são os mendigos negros.

Abre-se em mangues

de fôlhas duras e crespos

como um negro."

Desta maneira, o curso do rio, configurando o seu discurso (é através da abertura ou não que o rio fala ou silencia), refratário a peixes (brilho, inquietação), permite a "leitura" de uma realidade em que o natural (flôres) e o histórico (negros, mendigos) fazem parte de um mesmo repertório porque apontam para uma mesma condição.

Ainda mais: assim como na primeira estrofe o último verso nega a identificação, para a abertura, entre rio/peixe (aos, nos e em determinam o sentido da identificação), assim a singularização de negro, no último verso da segunda, afirma uma identificação que é negativa, sobretudo em face dos três versos centrais da estrofe ("Abre-se numa flora/suja e mais mendiga/como são os mendigos negros.").

Na verdade, à abertura cada vez maior da imagem inicial (flôres, flora, mangue) corresponde o fechamento progressivo do têrmo (histórico) de comparação (como negros, como são comoum).

É êste "fechamento" que vai responder pelas imagens de estagnação das estrofes seguintes: a "terra negra" que aparece nas oitava e nona estrofes existe, em razão dos símiles anteriores, num nível de percepção em que o natural e o histórico se confundem. Por isso, a partir da décima primeira estrofe o discurso acêrca da paisagem se faz explícitamente temporal, permitindo $o$ aparecimento de outros têrmos de comparação marcados pela negatividade preparada pela identificação flôres/negros mendigos.

"Ele tinha algo, então da estagnação de um louco. Algo da estagnação do hospital, da penitenciária, dos asilos, da vida suja e abafada (de roupa suja e abafada) 


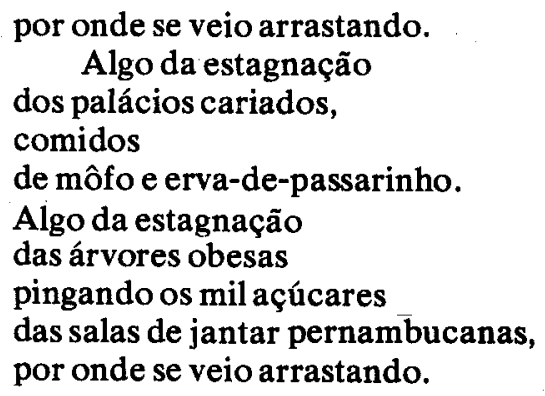

Dêste modo, o mesmo verso final das duas estrofes, sendo "descritivo" com relação ao curso do rio/cão, é antes "narrativo" (para usar os têrmos de George Lukács) ${ }^{8}$, se visto na perspectiva do seu discurso.

Assim é que, se na primeira estrofe, a estagnação é dada não sòmente pela associação do segundo verso como pelo espaço equivalente através do qual o rio cumpre o seu curso, da mesma maneira na segunda estrofe a imagem do segundo verso ("palácios cariados") vincula o espaço, de "árvores obesas/pingando os mil açúcares", por meio do qual o curso do rio/cão vai oferecendo os elementos configuradores de seu discurso. As qualificações do quinto verso da primeira estrofe, servindo tanto para vida quanto para roupa, e neste sentido funcionando como instrumento de caracterização regressiva, não apenas apontam para o movimento do rio/cão que se quer descrever, como semeiam os germes de uma relação negativa entre o discurso e a paisagem que se explicita na décima terceira estrofe:

"(É nelas, mas de costas para o rio, que "as grandes famílias espirituais" da cidade chocam os ovos gordos de sua prosa.

Na paz redonda das cozinhas, ei-las a revolver viciosamente seus caldeirões de preguiça viscosa)."

Fica evidenciado, dêste modo, o fato de que o verso final comum às duas estrofes anteriores ("por onde se veio arrastando") possui um teor "narrativo" capaz de transcender a primeira conotação, "descritiva", de seu uso.

Pela leitura da estrofe entre parêntese, fica-se sabendo que o movimento do rio/cão corresponde, por oposição, a uma paisagem que recusa o seu discurso. Na verdade, a citação irônica do terceiro verso, assim como os seus produtos "de costas para o rio", indicam o modo pelo qual o discurso "sociológico" "das salas de jantar pernambucanas", "os ovos gordos/de sua prosa", opõem-se ao do rio/cão. (Está claro que a referência 
inclui desde os romances regionais de "ciclos da cana-de-açúcar" até as interpretações "canavieiras" de uma certa história cultural que os legitima).

Mais do que o curso do rio, portanto, o que se visa é o seu discurso, a dialética entre os vários elementos que compõem não sòmente a paisagem pela qual êle se arrasta mas o próprio modo de articulação entre os dois, riopaisagem. $E$ isto ainda melhor se esclarece através das interrogações propostas pelas duas estrofes finais: retomando um dos têrmos relacionais da tessitura imagística inícial-fruta-, a água do rio é agora nomeada claramente. "Agua madura", tendo sido possível a partir do esquema de relações proposto no comêço do poema, representa o paroxismo da identificação perseguida dos elementos naturais $\mathrm{e}$ históricos. $\mathrm{O}$ "amadurecimento" da água traduz a passagem do rio/cão por uma paisagem tanto histórica quanto natural. Da mesma maneira, ao retomar o esquema de imagens com que, na terceira estrofe, nega o conhecimento do rio/cão em face de uma tradição "emplumada", fonte e mesmo chuva azul, que se dilui nos últimos versos através dos "olhos pintados de azul", a interrogante é mais do que uma retórica lírica para ser uma crítica do discurso tradicional codificado "nos mapas" do último verso.

\author{
"Aquêle rio \\ saltou alegre em alguma parte? \\ Foi canção ou fonte \\ em alguma parte? \\ Por que então seus olhos \\ vinham pintados de azul \\ nos mapas?"
}

Desfeita a trama de uma paisagem dividida, em que o rio/cão passa pela cidade, arrastando troncos e bois mortos e também os restos melosos de história das casas-grandes às suas beiras, é possível partir para a paisagem unificada pela lama e pelo homem-lama que a habita.

Desde os seus inícios, a segunda paisagem se contrapõe à passividade da primeira: o verbo utilizado na primeira estrofe tem a fôrça de uma explosão, de uma explosão, é verdade, entre restos:

\author{
"Entre a paisagem \\ o rio fluía \\ como uma espada de líquido espêsso. \\ Como um cão \\ humilde e espêsso."
}

Vê-se, assim, de que modo é retomado um dos têrmos-espada- do esquema de imagens do comêço do poema. Já que nas estrofes finais da primeira parte fruta havia servido, como se viu, a fim de veicular a historicidade do rio/cão, agora é espada que, servindo de têrmo de comparação, orienta o sentido de dinamicidade com que o rio/cão é apanhado numa paisagem que lhe é conatural. Por ser "entre a paisagem", é que é possível usar o verbo fluir. Isto seria, todavia, ainda pouco, dada a 
qualificação escolhida para espada ("de líquido espêsso"). Por isso, na estrofe seguinte, a paisagem é melhor definida no mesmo momento em que os têrmos da imagem anterior são melhor explicitados: "humilde e espêsso" utilizados para cão, através dos quais a identificação com o rio/espada se torna patente, projeta-se para o homem com que se identifica. (A repetição do verbo entre parêntese acentua o sentido com que é usado).

"Entre a paisagem

de homens plantados na lama;

de casas de lama

plantados em ilhas

coaguladas na lama;

paisagem de anfíbios

de lama e lama."

Na parte final do poema, o sentido de espêsso melhor ainda se delimitará: "O que vive choca, / tem dentes, arestas, é espêsso./O que vive é espêsso/como um cão, um homem,/como aquêle rio./Como todo o real/é espêsso."

Por enquanto, contudo, a introdução do vehicle tem a sua missão limitada: o que importa é o que se diz nos dois últimos versos, a mudança de uma paisagem em que se passa, ou se arrasta, para uma "de anfíbios".

Está completo o círculo: agora é possível utilizar a metáfora inicial do título para uma compreensão mais abrangente de seu universo de significação. A unidade paisagem/homem legitima a volta à negatividade, ao mesmo tempo que esta é desdobrada em função da crítica do discurso contida nas últimas estrofes da primeira paisagem. Neste sentido, pode-se dizer que o núcleo essencial desta segunda paisagem é a redução ao histórico de um esquema imagístico orientado para a naturalidade. Por isso, a identificação homem-rio (=cão sem plumas) funciona, nesta segunda paisagem, como módulo estrutural narrativo,consumindo as oposições construídas na primeira. Exemplo disto é o uso do verbo saber, não mais obedecendo ao esquema não saber/saber,mas em sentido de ampliação: o rio sabia, sabia também, $e$ sabia, etc. $\mathrm{E}$ assim como o conhecimento do rio não podia ser o das "grandes famílias espirituais da cidade" que para êle voltava as costas, só em parte é êle dos homens que, ao invés de "palácios cariados", habitam "sobrados ossudos" e que "secam/até sua mais funda caliça." Estes homens da cidade, "vestidos de brim", ainda são "emplumados" para o conhecimento do rio/cão. Por isso, coerente com a definição do homem/cão sem plumas que se havia dado nas terceira e quarta estrofes (terminando pelos versos "é quando a alguma coisa/roem tão fundo/até o que não tem"), na oitava estrofe está explicitada a sabedoria do rio/cão:

"Mas êle conhecia melhor os homens sem pluma. Estes 


\author{
secam \\ ainda mais além \\ de sua caliça extrema; \\ ainda mais além \\ de sua palha; \\ mais além \\ da palha de seu chapéu; \\ mais além \\ até \\ da camisa que não têm; \\ muito mais além do nome \\ mesmo escrito na fôlha \\ do papel mais sêco."
}

Este conhecimento, entretanto, só se realiza na medida em que o rio, "desemplumado" pelo poeta desde o início, tem o seu discurso adequado à paisagem em que se encontra. Para saber do homem-lama, do homem sem pluma, a linguagem do rio se faz lama na qual aquêle se perde:

\author{
“ $\mathrm{Na}$ água do rio, \\ lentamente, \\ se vão perdendo \\ em lama; numa lama \\ que pouco a pouco \\ também não pode falar: \\ que pouco a pouco \\ ganha os gestos defuntos \\ da lama; \\ o sangue de goma, \\ oôlho paralítico \\ da lama."
}

As duas estrofes finais desta segunda paisagem vão, assim, dar indicações sôbre o sentido dêste homem extraído pelo rio/cão de um universo de significações em que a sedimentação das "plumas" e do "discurso" tornava difícil. Por isso, elas estão orientadas para a obtenção do espêsso que é viável ainda se ter, depois de reduzido o homem à sua condição de lama. A redução pela imagem, que já se viu como base da composição do texto, é, desta maneira, a estratégia utilizada para o discurso, não mais do rio mas do poeta, acêrca do homem reduzido. Uma especie de isomorfismo no nível da metáfora. Que se estende através da própria designação escolhida para a terceira parte do poema: ao dizer "Fábula do Capibaribe" (no mesmo sentido em que antes falara de "Fábula de Anfion"), a discussão dos limites do rio, tendo por horizonte o mar, é também a da linguagem usada para, por seu intermédio, poder falar de uma certa realidade. Assim como a "Fábula de Anfion" já por si representava a escolha de uma linha de oposição à "poesia", a do Capibaribe, depois das paisagens recusadas ou 
integradas pelo seu discurso, inclui a desmontagem do quadro imagístico emoldurado pelo rio/cão no momento em que são retomados alguns de seus instrumentos fundamentais.

Dêste modo, a designação desta terceira parte tem, pelo menos, uma dupla função: por um lado, ela é a estória do combate travado pelo rio/cão com o mar e que, sobretudo, provém do próprio fechamento do rio/cão sôbre si mesmo, sôbre a sua condição de lama. E o que se lề, por exemplo, na estrofe em que a relação rio-mendigo é recuperada:
"O rio teme aquêle mar
como um cachorro
teme uma porta entretanto aberta, como um mendigo,
a igreja aparentemente aberta."

Deixando de lado a notável mestria em jogar, no terceiro verso, com a possibilidade de formação de um nôvo vocábulo a partir da congeminação porta aberta e o uso da conjunção (por onde se lê porta entreaberta), e que vem reforçar o sentido da oposição fechamento/abertura, o que ressalta do texto é o combate entre o rio-cachorro-mendigo e a condição de abertura representada pelo mar. Por outrolado, todavia, existe uma espécie de moral para a fábula centrada na lição oferecida pelo combate tanto para a linguagem do rio/cão em confronto com a do mar, quanto para a do poema que, em dois parênteses decisivos, discute os têrmos relacionais de sua tessitura. Uma e outra linguagens, entretanto, terminam por ser vinculadas pela "ética" do texto que prepara o discurso da parte final. Conhecendo pelo rio/cão, por suas paisagens e sua estória, sua "fábula", o poeta reflete sôbre o seu instrumento a tal ponto que o seu conhecimento passa a depender do sentido que fôr capaz de extrair dos têrmos postos em jôgo. Neste sentido, vale a pena examinar de mais perto o esquema adotado para a "Fábula".

$\mathrm{O}$ argumento do texto, iniciando-se pelas duas primeiras estrofes, é interrompido até a quinta, quando então, a partir da estrofe já transcrita, as relações de oposição rio/mar são aprofundadas. A partir da décima estrofe surge o segundo parêntese que, tomando três estrofes, encerra esta parte do poema.

Quanto ao argumento, existem dois segmentos básicos que intensificam a oposição rio/mar: de um lado, é a relação fechamento/abertura dada em têrmos de rejeição e de destruição:

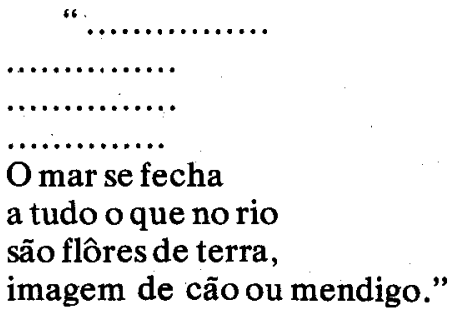


Por onde já se vê o sentido da recusa do rio pelo mar: na verdade, o que se rejeita é antes de tudo aquilo que, no poema, se construiu como imagem negativa da condição do rio/cão. O último verso não deixa espaço para dúvidas a respeito. $O$ que é mais: são os próprios tropos criados pelo poeta, produtos de sua linguagem, que sofrem o embate com uma outra linguagem-a do mar- que os refuta. Assim na estrofe seguinte, ainda dentro de um primeiro círculo de segmentos básicos do argumento do texto:

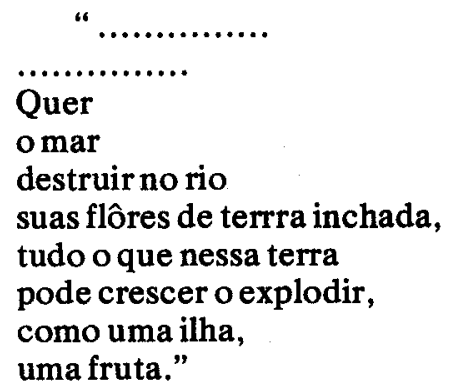

O último verso, mais uma vez, retomando um dos têrmos relacionais do início do poema, deixa ver em que medida o combate entre rio e mar é antes uma estratégia para falar da linguagem do poema, do conflito de suas linguagens.

Por outro lado, o argumento do texto tem a oposição rio/mar intensificada por uma espécie de movimento de solidariedade que tanto vai estar no poema "Rios sem discurso", que de mais perto segue o esquema aqui elaborado, quanto no texto, do mesmo $A$ Educafáo pela Pedra, "Tecendo a manhä".

\author{
“Mas antes de ir ao mar \\ o rio se detém \\ em mangues de água parada. \\ Junta-se o rio \\ a outros rios \\ numa laguna, em pântanos \\ onde. fria. a vida ferve. \\ Junta-se o rio \\ a outros rios. \\ Juntos, \\ todos os rios \\ preparam sua luta \\ de água parada, \\ sua luta \\ de fruta parada."
}

Este movimento, no entanto, não está sobreposto ao texto: como naqueles poemas posteriores referidos, a aglutinação dos referentes que o texto encerra é dependente daquela que a própria linguagem do poema 
determina. Assim, à reiteração vocabular soma-se à sintática na configuração de um rítmo de espera, de preparação, cujo componente semântico é dado, sobretudo, pelos dois últimos versos de cada uma das estrofes. No primeiro nível, está a qualificação redundante de mangues ("de água parada") que orienta, na segunda estrofe, a de luta ("de água parada"), para reverter ao último verso da primeira ao ser utilizada para fruta. Neste sentido, é o último verso da primeira estrofe que, por uma oposição de seus têrmos (fria-ferve), caracteriza não só a vida dos rios que se agrupam, como o modo pelo qual reajem ao desafio do mar. Na verdade, como se torna explícito no segundo parêntese, a identificação mangue/fruta, reduzindo os têrmos da máquina imagística posta em funcionamento nas duas paisagens do poema, é dada nestas duas estrofes através da qualificação de que se reveste a luta, não só preparada, mas parada, que a aglutinação dos rios promete.

Por outro lado, a reiteração sintática que está, por exemplo, nos quatro primeiros versos da segunda estrofe concorre para que entre o que o texto diz-o movimento de solidariedade referido-e a sua linguagem passe a existir também o mesmo movimento. Mas esta discussão da linguagem da fábula implícita em sua narração, transformando o argumento na moral a ser extraída, só é possível porque, nos dois parênteses que interrompen o fluxo narrativo, o poeta orienta o leitor na decifração das imagens de que usa, desmetaforizando os seus têrmos. (Embora, como se vai ver, parta para a criação de uma outra metáfora que tem de ver com a própria reflexão que o texto encerra).

Ambos os parênteses começam, por isso, como comentários às imagens forjadas ou recuperadas no correr da fábula.

Assim é que, no primeiro, a partir da estrofe anterior em que se trata dos limites marinhos do rio ("No extremo do rio/o mar se estendia, como camisa ou lençol,"), começa-se por indicar a origem e osentido da imagem a ser adotada:

"(Como o rio era um cachorro, o mar podia ser uma bandeira azul e branca desdobrada no extremo do curso -ou do mastro-do rio."

Origem: a oposição requerida para a imagem do rio/cão através da qual se dá o combate entre o rio e o mar.

Sentido: possibilidade de um têrmo comparativo (bandeira, por exemplo) que, sendo "azul e branca", "desdobrada", estabeleça um espaço distanciador entre as condições do mar e do rio/cão.

Sendo, portanto, dois cursos que se opõem (basta lembrar a côr, o negro, escolhida para antes nomear as flôres do rio, e a combinação 
heráldica agora sugerida para o mar, para a sua bandeira), não é de espantar que à imagem inicial junte-se a de uma persona que, poeta, é capaz de registrar, no texto, o seu oposto.

Da oposição de cursos à de discursos: uma passagem reiterativa neste poema de João Cabral.

Refiro-me ao símile que está entre o terceiro e o quarto versos da quinta estrofe:

\author{
"Uma bandeira \\ que tivesse dentes: \\ como um poeta puro \\ polindo esqueletos, \\ como um roedor puro, \\ um polícia puro, \\ elaborando esqueletos, \\ o mar, \\ com afã, \\ está sempre outra vez lavando \\ seu puro esqueleto de areia."
}

Em meio de outros, provocados por uma rápida associação de campos semânticos (dente-roedor-esqueleto-polícia), o símile em si não tem importância. Esta surge, entretanto, a partir da estrofe seguinte quando, então, a referência ao discurso se faz explícita: o silêncio do mar, a sua "pureza", vincula-se ao exercício repetitivo que tanto está em "polindo" (e a ironia com relação ao poema de corte parnasiano-simbolista é evidente), quanto no "professor de geometria"-último verso dêste parêntese.

Dêste modo, convergindo para a crítica irônica de uma linguagem- a "azul e branca" do mar-, êstes versos constituem o primeiro desdobramento de uma reflexão sôbre dois discursos/cursos que se opōem.

Assim sendo, no segundo momento de interrupção do argumento da fábula, é a partir da imagem criada pelas relaçōes entre mangue e fruta, a imagem de expectação de luta, que surge o comentário das imagens utilizadas:

"(Como o rio era um cachorro, como o mar era uma bandeira, aquêles mangues são uma enorme fruta:"

Está dito o essencial: a equação proposta pela estrofe, explicitando o mecanismo de formação das imagens, desmonta a certeza por acaso existente de uma adequação entre os têrmos escolhidos.

Não sòmente se havia dito antes que "o mar podia ser uma bandeira", insistindo-se assim no possível (na acepcão em que Haroldo de Campos usa o têrmo em texto já transcrito), como agora a própria qualificação para o 
rio/cão (mangues, fruta) é proposta ad argumentandum. Não importa a adequação "polida" desde que o que se diz é também, e sobretudo, uma condição "sem plumas". Neste sentido, o açúcar que esta fruta trabalha, ainda "depois de cortada", por certo só por oposição tem de ver com aquêle que pinga sôbre os salōes senhoriais da primeira paisagem do poema.

Por outro lado, todavia, desde que são possíveis, mesmo em condição de mangue, "... as ilhas súbitas/aflorando alegres" que resultam de um trabalho "paciente e útil", terminam por justificar o trajeto "gôta a gôta" "até uma nova planta", como se diz na última estrofe.

É, na verdade, uma redução. Mas uma redução conquistada -eis a matéria de que se nutre o "Discurso" final do texto.

A trama de referências desta parte final do poema é de tal ordem que eu diria ser impossível a sua compreensão sem, a todo instante, voltar-se a momentos diversos da obra do poeta. Nãó apenas, como parece óbvio, às três partes anteriores.

$\hat{E}$ o que acontece, por exemplo, com o tratamento da memória, fazendo o leitor regressar ao oposto de Pedra do Sono: agora não se trata de destruí-la, de perdê-la, a fim de possibilitar o "sono do jardineiro", da "Antiode", pelo qual escapa a "poesia-flor". A memória que se nomeia no segundo verso é não sòmente aceita mas responsavel também por aquela lucidez que Costa Lima, por exemplo, observou como paroxismo desta parte d'O cão sem plumas. ${ }^{9}$

“Aquêle rio
está na memória
como um cão vivo
dentro de uma sala.
Como um cão vivo
dentro de um bôlso.
Como um cão vivo
debaixo dos lençóis,
debaixo da camisa,
da pele."

Na verdade, "sala", "bôlso", "lençóis", "camisa" e "pele", configurando o movimento redutor das imagens, ecoam momentos diferentes de sua obra em que, pela tensão entre sono e vigília, buscava-se o poema para além dos restos da memória, recusado se trazido no "colête da lembrança", como está na "Psicologia da composição".

A qualificação que se dá agora a cão, no entanto, depois de todo o périplo de redução por êle percorrido, é o passo para fora do silêncio ameaçador: a afirmação de vida pelo cão, e não de sua vida pelo poeta, permite a concretização daquilo com que sonhava, ainda sonhava, um dos personagens d'Os três mal-amados, isto é, o poeta pode "discursar" pelo rio porque o eu texto já não é diferente do curso daquele. Chega-se àquela 
mimese projetada por Raimundo:

"Nessa fôlha eu construirei um objeto sólido que depois imitarei, o qual depois me definirá."

É neste sentido que, a meu ver, deve-se entender a escolha do título desta terceira parte: o poeta fala pelo Capibaribe, de quem se diz ser o "Discurso", não porque o substitua (como n' $O$ Rio será substituído por êle) mas porque de tal modo linguagem (do poeta) e objeto (o Capibaribe) tornaram-se dependentes que o "Discurso" dêste é necessáriamente o curso daquela.

Por isso mesmo, só em parte concordo com a afirmação de Benedito Nunes ao encerrar as suas análises sôbre o livro de João Cabral.

"Ao fim, -diz o crítico- o objeto do discurso poético torna-se discurso do próprio objeto, no sentido de que a ética do rio, da qual o poeta se faz intérprete, é lição extraída das próprias águas de Capibaribe" . ${ }^{10}$

E digo "em parte" desde que, embora aceitando as bases da argumentação, não creio correta a afirmação de que se trata agora de "discurso do próprio objeto". O "Discurso" continua sendo o do poeta e o seu objeto é ainda o rio/cão: a diferença, e o que explica o título, está em que o "Discurso" do poeta se fêz de tal modo mimético com relação à "moral" que foi possível extrair da "Fábula do Capibaribe" que a sua definição, e portanto a de seu "Discurso", conforme as antigas aspirações de Raimundo, é dada pela realidade do rio/cão por êle construída.

Dêste modo, a lição é menos "extraída das próprias águas do Capibaribe" do que do objeto construído (o poema) por intermédio do qual foi possível apreendê-las.

Quer dizer: a realidade do Capibaribe que agora se oferece como "lição" não está antes nem depois da composição do poema, do seu processo de composição, em que, como se viu, o tecido imagístico é constantemente rasgado em função de uma crítica incessante dos elementos de comunicação. Dizendo de outro modo, a realidade do rio/cão inscreve-se na linguagem que a discute e comunica. Assim como não se chega a dizer de sua vida, de que êle vive, sem passar pela trítica de suas paisagens de morte, assim a designação de uma realidade espêssa não se efetiva sem que haja a crítica da própria designação.

Vida e espessura, planos desta parte final do poema, são articuladas na medida em que linguagem e realidade convergem na formação de um espaço a que, agora, se pode chamar de poético.

Completa-se assim o círculo iniciado pela recusa: a aceitação da vida, de tudo o que na vida é salto para fora do silêncio, da estagnação dos mangues, termina por ser a recusa de uma linguagem de desvio.

\author{
"O que vive \\ incomoda de vida \\ o silêncio, o sono, o corpo
}




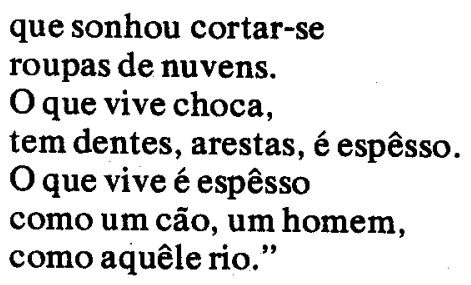

Desta maneira, se, como já foi dito, a adequação entre os têrmos de comparação não parece ser um projeto na obra de João Cabral, pelo contrário a possibilidade de escolhas diferentes pretende mesmo indicar a precariedade do "polimento" parnasiano-simbolista das imagens, é porque há uma outra adequação que ela persegue. A de linguagem e realidade, a que o leva a referir-se, na estrofe citada, às "roupas de nuvens" que recobrem o corpo incomodado pelo que é vivo, espêsso. A de uma linguagem que dê conta da espessura do real e não apenas o embeleze graças aos artifícios da "poesia".

Seria pouco, entretanto, dizer que, ao final dêste poema, João Cabral demonstra o seu direcionamento para o real: na verdade, se, de fato, êste existe mais patente do que em textos anteriores não é porque a sua mirada seja agora regional e sim porque a sua linguagem desfêz-se das "roupas de nuvens" que por acaso a recobriam.

$\hat{E}$ a realidade da linguagem, a sua viva e espêssa função no plano da invenção poética, que permite a maior abertura para a realidade de circunstância que se incorpora ao texto. Ao fazer-se real no espaço do poema, a linguagem cria a realidade, na medida em que esta só faz parte daquele espaço por sua efetivação. E o que significa isto?

Antes da mais nada- como êste poema de João Cabral bem o demonstra-, a recusa de estereótipos que impeçam o encontro do escritor com a linguagem, instaurando a confortável certeza e a tranqüilidade dos mecanismos bem oleados, mas de ação limitada. A linguagem, para retomar os têrmos do poeta, se vive para o escritor, como tudo o que vive, também incomoda.

Mais ainda: o rio "discursa" sôbre vida e espessura a partir de sua linguagem aprisionada na lama, da mesma maneira que, para o poeta, "discursar" sôbre o rio exige a passagem pela redução de tudo o que em suas imagens não revela a condição do rio/cão e toma o partido do embandeirado, emplumado, mar.

Assim, "o cão sem plumas" é também o poema pelo qual o outro é comunicado. E é por ser assim que êle, o poema "sem adornos", pode falar do real e de sua espessura: reduzido à linguagem, a densidade é a sua medida.

Desta forma, o "Discurso" com que o poema se encerra é tanto a comunicação de uma realidade, de uma vida, de uma espessura, conquistadas "gôta a gôta", quanto a de uma composição que, em seu 
trajeto, obedece aos mesmos passos dados pela primeira. $O$ parêntese da última estrofe é revelador neste sentido:

$\quad$ "Espêsso
porque é mais espêssa
a vida que se luta
cada dia,
o dia que se adquire
cada dia
(como uma ave
que vai cada segundo
conquistando seu vôo)."

Já se sabe, desde a leitura do poema "A Bailarina", de $O$ Engenheiro, em que medida a imagem do pássaro, do vôo, está vinculada à do poema almejado, alvo na mira do poeta. Sendo assim, tanto "a vida que se luta" quanto "o dia que se adquire" têm a sua espessura determinada pelo próprio teor das orações adjetivas: o gerúndio do último verso não faz senão confirmar o processo pelo qual tanto vida e dia, quanto poema, são atingidos. A própria reiteração, se mais fôsse preciso, aponta para as raízes do procedimento. Orientando o poema para a "prosa", a repetição explicativa tem uma outra função - esta genuinamente poética: a de falar do que incomoda - vida, espessura- procurando o isomorfismo de uma expressão que não agrada, nem acaricia, ao contrário fere e incomoda. Realidade e espessura são, dêste modo, confundidos pelo exercício de uma linguagem que, por sua redução, cria o seu espaço real e espêsso. Na verdade, sem deixar de ser o Capibaribe, o rio/cão passa a ser a própria linguagem através da qual a redução se opera: o que mais importa não é o seu componente regional mas o modo pelo qual êle indica uma condição, seja um cachorro, uma maçã ou um homem, como está nas quarta e quinta estrofes:

"Como todo o real é espêsso.

Aquêle rio

é espêsso e real.

Como uma maçã

é espêssa.

Como um cachorro

é mais espêsso do que uma maçã.

Como é mais espêsso

o sangue do cachorro

do que o próprio cachorro.

Como é mais espêsso

um homem

do que o sangue de um cachorro.

Como é muito mais espêsso

o sangue de um homem

do que o sonho de um homem. 


\author{
Espêsso \\ como uma maçã é espêssa. \\ Como uma maçã \\ é muito mais espêssa \\ se um homem a come \\ do que se um homem a vê. \\ Como é ainda mais espêssa \\ se a fome a come. \\ Como é ainda muito mais espêssa \\ se a não pode comer \\ a fome que a vê."
}

Do antropomorfismo do rio/cão - suas paisagens, sua fábula-, chega-se assim ao humanismo conquistado. A vida que comanda o nascimento da imagem do sangue é orientada, em ambas as estrofes, para uma noção específica do homem. Neste sentido a derrota do sonho, nos últimos versos da primeira, encontra o seu correlato na fome da última estrofe. Vida-realespêsso-homem são, dêste modo, os têrmos do curso (real, espêsso) de um discurso (real, espêsso) que, ao negar o sonho, afirma a prevalência da fome.

Esta abertura para o geral, a abstração conseguida, não se fêz, portanto, sem uma estação rimbaudiana nos infernos do particular e do concreto. Sobretudo neste "particular" do poema que é a linguagem. $O$ "direcionamento para o real", a que se fazia referência, é, de fato, conquistado na medida em que êle é, no espaço poético, um direcionamento para a linguagem. Chega-se assim à afirmação de que se $O$ cão sem plumas é mais "real" do que textos anteriores é porque êle é "mais" poema, isto é, cava mais fundo nas possibilidades de articulação entre o fazer e o dizer, a composição e a comunicação.

Por ser assim é que, como se disse no início, se, por um lado, o poema vem apontar, na perspectiva do projeto de João Cabral, para uma explicitação do regional, por outro, contudo, ao fazer-se momento privilegiado de intensificação das relações entre composição e comunicação, êle escapa a uma definição simplesmente localista. Dêste modo, a sua importância, para a evolução de João Cabral, não está numa hipotética tomada de consciência do mundo exterior, mas no modo pelo qual êle vincula linguagem e realidade, estabelecendo o cânon de sua poesia. E êste é dado, na verdade, pela tensão resultante da consciência, não do mundo exterior e da circunstância, mas da viabilidade de sua representação. É um poema crítico não porque apenas fale de lama, homem-lama, vidalama em oposição à condição emplumada, mas porque se desempluma para permitir o discurso, criando, desta maneira, uma relação poética de dependência entre significado e significante. Em resumo, pode-se dizer que é a invenção de uma estratégia-a desmontagem interna das imagens na formação de sua "metáfora epistemológica" - o que caracteriza a realização 
dêste texto de 1950 , abrindo o caminho para que a sua obra seguinte possa ser vista como aproximação ou distanciamento do roteiro traçado neste poema germinal. Por isso, pôde Benedito Nunes falar dêste poema como o momento em que "se dá a bifurcação dessa arte em dois tipos de dicção"1, ou Haroldo de Campos em "estágio de trânsito entre ambas as dicções do poeta"12. A sincronia da segunda afirmação vem completar a diacronia da primeira: a existência de "duas águas" é anterior à designação das obras do poeta em 1956 desde que ela se incrusta na própria tensão entre dizer o fazer, caracterizando uma diç̧ão que não a dissimula através de efeitos "poéticos" mas, ao contrário, procura enfrentar abertamente o seu desafio.

$\mathrm{Na}$ verdade, a estratégia de uma desmetaforização de seus têrmos, ao mesmo tempo que livrava o poeta de uma diluição do lirismo (alertando-o para o uso temático e fácil das imagens), oferecia o caminho para que, em sua obra, fôsse possível a convivência de uma intensa preocupação técnica e a expressão de componentes tematizados por sua experiência. Sòmente a ironia implícita na estratégia inventada permitiria a historicidade do poema sem o risco de um historicismo à margem do texto.

Universidade de São Paulo

JOÃO ALEXANDRE BARBOSA

\section{NOTAS}

${ }^{1}$ Refiro-me a Angel Crespo e Pilar Gomez Bedate, "Realidad y forma en la poesía de João Cabral de Melo", em Revista de Cultura Brasileña, T.III, mar.1964, No. 8, p. 36.

${ }^{2}$ Idem, ibidem, pp. 37-8.

3 Idem, ibidem, p. 36.

${ }^{4}$ Idem, ibidem, p. 37.

${ }^{5}$ Cf. Metalinguagem. Ensaios de teoria o crítica liteníria. Petrópolis: (Coleção Nosso Tempo), Vozes, 1967, pp. 72-3.

${ }^{6}$ Cf. Pequeno Dicionário Brasileiro da Língua Portuguessa. Dir. de Aurélio Buarque de Holanda Ferreira, 11a ed. R. Janeiro: Civilização Brasileira, (1967), p. 952.

${ }^{7}$ Cf. Jodo Cabral de Melo Neto. (Rio de Janeiro): (Coleção Poetas Modernos do Brasil) 1 , Vozes (1971),pp. 66.

${ }^{8}$ Refiro-me às distinçōes estabelecidas entre Tolstoi e Zola no conhecido ensaio "Narrar ou Descrever?".

${ }^{9}$ Cf. Lira e A ntilira. (Rio de Janeiro): Civilização Brasileira, (1965), p. 303.

10 Op. cit. p. 71.

${ }^{11}$ Idem, ibidem, ib.

120 p. cit. p. 72. 
